УДК 316.7(=214.58):008(447)«20»]:78.071.2(092)

Рудніцька Олександра Олександрівна,

старший викладач кафедри режисури та акторської майстерності,

здобувач Національної академії керівних кадрів культури і мистецтв

oleksandrarudnitska@gmail.com

ORCID: 0000-0001-6654-6717

\title{
СОЦІОКУЛЬТУРНА ІНТЕГРАЦІЯ РОМІВ В УКРАЇНСЬКУ КУЛЬТУРУ ХХІ СТОЛІТТЯ (НА ПРИКЛАДІ ТВОРЧОСТІ ІГОРЯ КРИКУНОВА ТА ПЕТРА ЧОРНОГО)
}

Мета: дослідити соціокультурну інтеграцію ромів в українську культуру ХХІ століття, визначити феномен ромського мистецтва серед відомих діячів української сцени (на прикладі творчості Ігоря Крикунова, Петра Чорного), прослідкувати взаємозв'язок і взаємовпливи їхньої творчості на формування української культури. Методологія дослідження грунтується на використанні культурно-генетичного, соціологічного, структурносистемного, порівняльного методів для виявлення джерел походження і сутнісних характеристик представників різних етнічних груп ромів як специфічної складової культурного життя і новітньої структури українського соціуму. Наукова новизна статті полягає у тому, що в ній уперше визначається поняття «ромське мистецтво», проводиться порівняльна характеристика різних ромських груп (сервів, руска рома), виявляється походження, формування, сучасний стан та вплив ромського мистецтва на розвиток української культури XXI ст. Висновки. Соціокультурна інтеграція ромів має значний вплив на розвиток української культури XXI століття. В Україні проживає велика кількість ромських етногруп. Найбільшого поширення набули три групи ромського населення: серви, або українська рома, руська рома та ловарі. Роми активно включалися в суспільні процеси, привносячи в країну, в якій жили, власні культурні цінності. Так, в сучасному мистецтві досить важливим є внесок ромських митців. Дослідження творчості представників сучасного ромського мистецтва дає підстави стверджувати, що ці особистості позиціонують власну творчість невід’ємною частиною української культури. Це прослідковується на творчості Петра Чорного та Ігоря Крикунова, мистецтво яких є надбанням для української культури і яскраво демонструє соціокультурну інтеграцію ромів в українську культуру XXI століття.

Ключові слова: етнічна група, руска рома, серви, ромське мистецтво, Ігор Крикунов, Петро Чорний, культура України,соціокультурна інтеграція.

Рудницкая Александра Александровна, стариий преподаватель кафедры режиссуры и актерского мастерства, соискатель Наџиональной академии руководящих кадров культуры и искусств

Социокультурная интеграция ромов в украинскую культуру XXI века. (На примере творчества Игоря Крикунова и Петра Черного)

Цель: исследовать социокультурную интеграцию ромов в украинскую культуру XXI века, определить феномен ромского искусства среди известных деятелей украинской сцены (на примере творчества Игоря Крикунова, Петра Черного), проследить взаимосвязь и взаимное влияние их творчества на формирование украинской культуры. Методология исследования основана на использовании культурно-генетического, социологического, структурносистемного, сравнительного методов для выявления источников происхождения и сущностных характеристик представителей различных этнических групп ромов как специфической составляющей культурной жизни и новой структуры украинского социума. Научная новизна статьи заключается в том, что в ней впервые определяется понятие «ромское искусство», проводится сравнительная характеристика различных ромских групп (сервов и руска рома), выявляется происхождения, формирования, современное состояние и влияние ромского искусства на развитие украинской культуры XXI века. Выводы. Социокультурная интеграция ромов имеет значительное влияние на развитие украинской культуры XXI века. В Украине проживает большое количество ромских этногрупп. Наибольшее распространение получили три группы ромского населения: сервы, или украинские рома, русская рома и ловари. Ромы активно включались в общественные процессы, привнося в страну, в которой жили, собственные культурные ценности. Так, в современном искусстве весьма важным является вклад ромских деятелей. Исследование творчества представителей современного ромского искусства дает основания утверждать, что эти личности позиционируют собственное творчество неотъемлемой частью украинской культуры. Это прослеживается в творчестве Петра Черного и Игоря Крикунова, их икусство - приобретение для украинской культуры и ярко демонстрирует социокультурную интеграцию ромов в украинскую культуру XXI века.

Ключевые слова: этническая группа, руска рома, сервы, ромское искусство, Игорь Крикунов, Петр Черный, культура Украины, социокультурная интеграция.

Rudnitska Olexandra, Senior Lecturer, Department of Directing and Acting, PhD Candidate, Department of Cultural Studies, National Academy of Managerial Staff of Culture and Arts Sociocultural

Sociocultural integration of the Roma into Ukrainian culture of the XXI century (based on the work of Igor Krikunov and Petro Chornuy)

The purpose of the article is to explore the sociocultural integration of Roma into Ukrainian culture in the XXI century, to determine the phenomenon of Roma art among prominent figures in the Ukrainian scene (Based on the work of Igor

(СРудніцька О. О., 2019 
Krykunov, Petro Chornuy), to trace the interconnection and interplay of their creativity on the formation of Ukrainian culture. The methodology of the study is based on the use of cultural-genetic, sociological, structural-systemic, comparative methods for identifying sources of origin and essential characteristics of representatives of different ethnic groups of Roma as a specific component of cultural life and the newest structure of the Ukrainian society. The scientific novelty of the article is that it first defines the concept of "Roma art," compares the characteristics of different Roma groups ("servu" and Ruska Roma)), reveals the origin, formation, contemporary status, and influence of Roma art on the development of Ukrainian culture of the XXI century. Conclusions. The sociocultural integration of Roma has a significant impact on the development of Ukrainian culture of the XXI century. A large number of Roma ethnic groups live in Ukraine. Three groups of the Roma population were most widespread: "servu" or Ukrainian Roma, Ruska Roma, and "lovari" (Hungarian Roma). Roma were actively involved in social processes, bringing their own cultural values to the country where they lived. Yes, the contribution of Roma artists is quite essential in contemporary art. The study of the creativity of contemporary Roma art gives grounds to claim that these personalities position their creativity as an integral part of Ukrainian culture. This is reflected in the work of Petro Chornuy and Igor Krikunov; their creativity is an asset for the Ukrainian culture. It clearly demonstrates the sociocultural integration of the Roma into Ukrainian culture of the XXI century.

Key words: ethnic group, Ruska Roma, "servu", Roma art, Igor Krikunov, Petro Chernuy, Ukrainian culture, sociocultural integration.

Актуальність теми дослідження. Ромська культурна спадщина, у тому числі мистецтво, мають особливий етнокультурний показник. Це зумовлюється специфікою проживання нації, іiі історичними перспективами. Роми вирізняються багатим фольклором, музикою, танцем, мають своєрідний національний одяг. Ромське мистецтво наклало відбиток на українську культуру. Огляд таких соціокультурних понять, як середовище, цінності, соціокультурний простір, традиції, сім'я, їх специфічна роль і черговість створює принципово нові можливості щодо збереження ромської культурної спадщини, дозволяє з'ясувати його вплив на українську культуру XXI століття. Більш детальний розгляд основних характеристик ромів продемонструє їх специфіку самоідентифікації та інтеграції в сучасний світ.

Аналіз досліджень і публікацій. Дослідженню інтеграції ромів у сучасний світ приділяється значний інтерес. Сучасні дослідники-ромознавці активно висвітлюють специфіку ромського мистецтва та його особливості. Так наприклад, історик та етнограф О. Зіневич звертає увагу на специфіку творення етносоціальних груп, їх обрядовість й етнічну розрізненість, В.Бамбула досліджував освіту ромів, а також демократичні ініціативи населення. Успішними є роботи В.Наулко, Т.Чередниченко, О.Марушіакової, В. Попова та інших дослідників.

Проте, попри численні статті, монографії, дисертаційні дослідження, присвячені вивченню ромської культури, досліджень з інтеграції ромів у вітчизняній культурології немає. Мета дослідження полягає в тому, щоби проаналізувати соціокультурну інтеграцію ромів в українську культуру XXI століття, визначити феномен ромського мистецтва серед відомих діячів української сцени (на прикладі творчості Ігоря Крикунова, Петра Чорного), прослідкувати взаємозв'язок і взаємовпливи їхньої творчості на формування української культури.

Виклад основного матеріалу. Як зауважують В. Наулко та Н. Зіневич, в Україні проживає багато етнографічних груп ромів, серед яких влахи, кишинівці, келдерари, крими, ловари, расейці (гімпени), русска рома, серви, сервітіка рома, сінті, унгріко рома, урсари та ін. [1. С.23]. Найбільшого поширення набули три групи ромського населення, серед яких: серви, або українська рома, руська рома та ловарі. Представники різних соціальних груп мають власні ідентифікації, зокрема це демонструється як у соціальному житті, так і в культурній спадщині. Вони активно демонструють власну культурну спадщину, мають здобутки у творчості. Українські слухачі та глядачі поціновують їхні культурні надбання.

Сервами називали багатьох українських ромів, оскільки, як вважалося, вони прийшли в Україну 3 Румунії через Сербію, привласнивши собі назву серви - тобто українські роми. Ця етногрупа поширена також у північній частині Росії. Серви традиційно займалися торгівлею та обміном кіньми, ковальством, ворожінням, відзначилися як одна 3 найосвіченіших етногруп 3 широким спектром професій. Подібність обрядовості до слов'янського населення є визначним [2]. Це найбільш асимільована група. Представники сервів, як правило, займаються тими ж видами діяльності, що й українці, визначальними є лише екзотична зовнішність та культурна спадшина. Вони більш адаптовані до культури навколишнього етносу в порівнянні з іншими групами. Та найбільшого розвитку зазнали як творці циганського романсу. Основою для «циганських» романсів служили як російські народні пісні, так міські романси. Йому властиві, як зазначає Т. Чередниченко, «емоційна насиченість, поєднання співучості та декламаційності, специфічна гітарна фактура супроводу з переборами акордів і контрапунктуючою з вокальною мелодією басом» [3].

Російські роми, які мають самоназву руська рома - це етнічна група, що сформувалася в ПівнічноЗахідній частині Російської імперії й іммігрувала в XVIII столітті в Україну. Відрізняються переважанням запозиченої лексики з європейських субкультур [2]. Руська рома позиціонуються як засновники циганського театру. Відомий в усьому світі російський ромський театр «Ромен» був створений у Москві в 1931 році. Серед засновників - руська рома. Вони також стали провідними акторами театру. У Радянському Союзі діяльність театру «Ромен» сприймають як базову культуру ромів. Не можна не зважати на велику популярність таких відомих постатей сучасності як Дмитро Клімашенко, Петро Чорний, Ігор Крикунов (та його театр «Романс»); та інші представники ромської національності, що інтегрують ромське мистецтво в українську культуру. 
Дослідження творчості представників сучасного ромського мистецтва, дає підстави стверджувати, що ці особистості позиціонують власну творчість невід’ємною частиною української культури. Зупинимося більш детально на творчості Петра Чорного. Петро Чорний - український співак ромського походження, представник етногрупи «серви». Його бабуся - знаменита співачка Ляля Чорна, яка стала легендою Московського циганського театру «Ромен». Мати Петра - Галя Чорна, народна артистка РРФСР, відома виконавиця старовинних циганських пісень і романсів. Батько, Микола Федоренков, керував ансамблем «Циганські наспіви». Саме по лінії мами входить до ентногрупи українських ромів (сервів). Мати співака виросла в таборі, але мріяла, щоб у Петра була повна освіта. Тому у семирічному віці вступив до Київської музичної спеціалізованої школи-інтернату імені М. В. Лисенка. Отримавши музичну освіту, закінчив режисерсько-естрадний факультет ГІТІСу.

Співак, як представник ромської династії, популяризує національну культуру в Україні, наголошує на тому, що в українців і ромів багато спільного. Петро Чорний співає пісні не лише ромською, а й українською мовами. Цитата для ромів від П. Чорного: «Ром ромэса, гадже гаджеса» пов’язує зі шевченківськими «...i чужому научайтесь, й свого не цурайтесь». На одному з виступів співак назвав себе українським циганом [4]. В інтерв’ю газеті «Культура» Петро Чорний сказав: «Ви розумієте, я не ідентифікую - я несу культуру. I коли пишу такі рядки...», «...Україна - це Грушевський, Франко, Шевченко, Леся Українка - все, чим ми просякнуті від нігтя до волосся. І нам потрібно це нести і прагнути до краси, до популяризації культури» [3]. Петро Чорний в цьому ж інтерв'ю зазначив, що він разом, 3 такими ж відомими ромами Петром Клімашенком, Ігорем Крикуновим, Олександром Чукаленком своєю творчістю розвіює всі міфи й стереотипи про ромів, популяризує ромську культуру й не бачить себе в жодній з країн, окрім України. Спільним у ромів й українців $є$ відчуття й бажання свободи. Неодноразово Петро Чорний їздив на Схід України (Волноваха, Володарськ, Авдіївка) із благодійними концертами. Співак вважає, що артист не може буги аполітичним. Артист підкреслює, що українська культура відкрита для ромів. Як соліст-вокаліст, Петро Чорний багато працює в Україні та за кордоном, активно бере участь у Всеукраїнських фестивалях сучасної естрадної пісні. Репертуар співака різноманітний. Здебільшого це відомі циганські романси, авторські пісні та відомі українські пісні, також артист володіє музичними інструментами, зокрема, грає на фортепіано, а також читає вірші. Співак багато працює за кордоном, особисто знайомий з Дональдом Трампом. Переконаний, що репертуар має нести як гносеологічну, так і виховну функції. Хітами його репертуару стали як ромські «Далю даля», «Шалейла», «Ай дігі дай» так і україномовні та російськомовні «Отаман», «Лети на край», «Сердце, пой», «Серце львицы», «Я тебе дарю», «Белая сирень» та інші. Це мелодійні пісні для широкого голосового діапазону, яким володіє співак, у них передається не тільки ромська національна культура, але й колоритна українська музична українська культура.

Петро Чорний та Ігор Крикунов тісно спілкуються й дружать. Петро Чорний вважає Крикунова своїм творчим наставником і завжди прислухається до його порад та зауважень.

Найвідомішим представником етногрупи «руська рома» $є$ Ігор Крикунов - режисер, актор театру та кіно, культурно-мистецький діяч ромського походження. Він народився в Таганрозі, в Росії. Батьки Крикунова в своєму дитинстві жили в таборі й вели кочове життя, але сам Ігор Миколайович повністю виріс в оточенні гаджьо - «нециган». Після закінчення Щукінського училища-театру, одразу ж вступив на службу в Московський театр «Ромен», (художний керівник - Микола Сліченко). Ігор Миколайович 13 років був провідним актором театру «Ромен». Переїхав до Києва на запрошення театру на Подолі, де працював приблизно 10-ти років. А згодом, у 1993 році, відкрив власний театр - циганський театр «Романс», започаткувавши нову історію циганської культури в українському соціокультурному просторі [6].

За ініціативи Ігоря Миколайовича, в Києві вперше відбувся Міжнародний циганський фестиваль мистецтв «АМАЛА». («друзі» з ром.) Має звання народного артиста України (2007 р.). Комітет Міжнародних премій вручив Крикунову орден Миколая Чудотворця «за приумножение добра на земле». Також перший, хто отримав орден «Циганська зірка», який вручає національне культурне об'єднання «АМАЛА».

Дружина Крикунова Людмила також має ромське походження, однак належить до сервів (українських ромів). Мати Людмили - Жанна Карпенко - відома співачка, зокрема і циганських романсів. Нині в театрі «Романс» грають багато членів родини: дружина Людмила Крикунова (заслужена артистка України) та донька Жанна. Син Крикунових працює в царині шоу-бізнесу.

У 2003 році театр «Ромен» отримав статус державного із формулюванням «За гідний внесок у розвиток багатонаціональної культури України». Репертуар театру жанрово різноманітний, постійно оновлюється та осучаснюється. Ігор Крикунов прагне до симбіозу культур та національностей у виставах. Головною темою вистав $є$ загальнолюдські проблеми та переживання, такі як батьки та діти, любов до нації, культури, мистецтва та слова. Мета театру - відкрити культуру та світосприйняття ромів в своєму національному та українському побуті. Кожна вистава наповнена музикою вільних циган, вона дає можливість глядачу поринути в атмосферу циганських пристрастей, почуттів, безрозсудного кохання, а також відчути цю всеохоплюючу волю та почуття свободи. Окрім роботи на сцені свого рідного театру, «Романс» проводить гастролі у Київській області, всій Україні та за ії межами. За словами Ігоря Крикунова, театр не проповідує «циганщину» (термін I. К.), тобто під цим поняттям артист має на увазі перевдягнених артистів з бубнами з розважально-спрощеним, «ресторанним» репертуаром. «Часто нециганський артист, 
коли втрачає свою популярність, то переходить на циганський матеріал, щоб через емоцію, темперамент, динаміку, які властиві ромській культурі, зацікавити публіку. Творча спадщина нашого народу велика, а музика та пісні - це дорогоцінний скарб» - зауважує митець [5]. І. Крикунов заохочує всіх ромів учитись, отримувати освіту, бо лише освічена людина може при піднести свою культуру. Вважає, що роми настільки самобутні, що вони не асимілюються з іншими народами.

Ромський академічний музично-драматичний театр «Романс» Для збереження національної ідентичності взяв участь у міжнародному проекті «Захистимо пам'ять»: відкриття меморіалів ромам $\mathrm{i}$ євреям, загиблим під час німецької окупації 1941-1944 рр. Проект Фонду «Меморіал убитим євреям Європи» (Берлін) присвячений одній із забутих сторінок Другої світової війни. Як відомо, що жертвами німецької політики тотального винищення в окупованій Україні у 1941-1944 роках були роми.

Як Петро Чорний, так і Ігор Крикунов - ромської національності, проте $є$ представниками різних етнічних груп. Вони не приховували походження, більше того, батьки Крикунова були кочовими ромами. Обидва 3 дитинства залучені до мистецької освіти, здобули професійну вищу освіту в профільних закладах - ГІТІС та Щукінське училище. Якщо Петро Чорний більше позиціонує себе як співак, то Ігор Крикунов актор, режисер, керівник театрального колективу. Петро Чорний активно всіма доступними способами популяризує ромську культуру в Україні, наголошує на тому, що в українців і ромів багато спільного в культурі. П.Чорний співає пісні не лише ромською, а й українською мовами, багато гастролює, займається викладацькою діяльністю. Ігор Крикунов прагне до симбіозу культур та національностей у виставах. Творчість театру спрямовує на соціокультурність ромського мистецтва.

Наукова новизна статті полягає у тому, що в ній уперше визначається поняття «ромське мистецтво», проводиться порівняльна характеристика різних ромських груп (сервів, руска рома), на прикладі конкретних людей, відомих культурних діячів, показано тенденцію до виявлення походження, формування, сучасний стан та вплив ромського мистецтва на розвиток української культури XXI ст.

Висновки. Таким чином, соціокультурна інтеграція ромів має значний вплив на розвиток української культури XXI століття. В Україні проживає велика кількість ромських етногруп. Найбільшого поширення набули три групи ромського населення: серви, або українська рома, руська рома та ловарі. Роми активно включалися в суспільні процеси, привносячи в країну, в якій жили, власні культурні цінності. Так, в сучасному мистецтві досить важливим $\epsilon$ внесок ромських митців. Дослідження творчості представників сучасного ромського мистецтва дає підстави стверджувати, що ці особистості позиціонують власну творчість невід’ємною частиною української культури. Це прослідковується на творчості Петра Чорного та Ігоря Крикунова, творчість яких є надбанням для української культури XXI століття і яскраво демонструє соціокультурну інтеграцію ромів в українську культуру XXI століття.

\section{Jimepamypa}

1. Наулко В. І., Зіневич Н. О. Цигани в Україні. Енциклопедія історії України. В 10 т. Т. 1 / редкол.: В. А. Смолій та ін. Київ: Наук. думка, 2013. 688 с.

2. Серви // Циганські етногрупи на пострадянському просторі URL : http://gypsy-life.net/likbez.htm (дата звернення: 16.09.2019).

3. Чередниченко Т. Циганский романс. URL : https://www.belcanto.ru/cygansky.html (дата звернення: 10.09.2019).

4. Чорний П. Не уявляю, щоби давав концерт Геббельсу через «аполітичність». URL: https://glavredInfo /kultura/

304906-petr-chernyy-ne-predstavlyayu-chtoby-ya-dal-koncert-gebbelsu-iz-za-apolitichnosti.html (дата звернення: 30.08.2019).

5. Поліщук Т. Ми циганщину ніколи не проповідували. День. 2018. №23-24. С. 36. URL : https://day.kyiv.ua/uk/article/kultura/my-cyganshchynu-nikoly-ne-propoviduvaly (дата звернення: 11.09.2019).

6. Циганський академічний театр «Романс» офіщійна сторінка, URL : http://teatr-romans.com.ua (дата звернення: 12.09.2019).

7. Петро Чорний у Полтаві // 0532.uа. Сайт міста Полтави. URL : https://www.0532.ua/news/2301833/petro-cornij-upoltavi-rozpoviv-pro-batl-iz-trampom-robotu-na-zelenskogo-ta-rol-aski-v-neulovimyh-mstitelah (дата звернення: 10.09.2019).

\section{References}

1. Naulko, V. I., \& Zinevich, N. O. (2013). Gypsies in Ukraine. Encyclopedia of the History of Ukraine. Vol. 1. Kyiv: Naukova Dumka [in Ukrainian].

2. Services. Tsiganski etnogrupi on the injured space http://gypsy-life.net/likbez.htm [in Ukrainian].

3. Cherednichenko, T. Gypsy romance. Retrieved from https://www.belcanto.ru/cygansky.html [in Russian].

4. Chornyy, P. I Can't Imagine Gobbels' Concert Due to "Apoliticalism". Retrieved from https://glavred.info/kultura 1304906-petr-chernyy-ne-predstavlyayu-chtoby-ya-dal-koncert-gebbelsu-iz-za-apolitichnosti.html [in Ukrainian].

5. Polishchuk T. (2018). We have never preached the gypsy region. The Day newspaper, no 23-24. Retrieved from https://day.kyiv.ua/en/article/kultura/my-cyganshchynu-nikoly-ne-propoviduvaly [in Ukrainian].

6. Romance Romani. Academic Theater Official Page. Retrieved from http://teatr-romans.com.ua [in Ukrainian].

7. Peter Chornuy in Poltava (2019, February 12). 0532.ua. The site of the city of Poltava. Retrieved from https://www.0532.ua/news/2301833/petro-cornij-u-poltavi-rozpoviv-pro-batl-iz-trampom-robotu-na-zelenskogo-ta-rol-aski-vneulovimyh - mstitelah [in Ukrainian]. 